\title{
Wool production performance of Harnai sheep from Asghara valley, Sinjavi, District Ziarat
}

Farhat Abbas Bukhari ${ }^{1}$, Sarfraz Ahmad ${ }^{2}$, Muhammad Islam ${ }^{3}$, Tauseef Muhammad Asmat ${ }^{1}$, Majid Rafique ${ }^{1}$, Tahir Hameed ${ }^{1 *}$, Mohammad Zahid Mustafa ${ }^{1}$, Babar Hilal Abbasi ${ }^{1}$ and Irshad Ali $^{1}$

1. Center for Advanced Studies in Vaccinology and Biotechnology (CASVAB) University of Balochistan, Quetta-

Pakistan

2. Pakistan Agriculture Research Council (PARC), Islamabad-Pakistan

3. National Agriculture Research Council (NARC), Islamabad-Pakistan

*Corresponding author's email: tahirquetta@ hotmail.com

Citation

Farhat Abbas Bukhari, Sarfaraz Ahmad, Muhammad Islam, Tauseef M Asmat, Majid Rafique, Tahir Hameed, Mohammad Zahid Mustafa, Babar Hilal Abbasi and Irshad Ali. Wool production performance of Harnai sheep from Asghara valley, Sinjavi, District Ziarat. Pure and Applied Biology. Vol. 5, Issue 4, pp1151-1159. http://dx.doi.org/10.19045/bspab.2016.50138

Received: 24/08/2016 Revised: 18/10/2016

Accepted: $24 / 10 / 2016$

Online First: 28/10/2016

\section{Abstract}

The study was designed to investigate the wool production performance of Harnai sheep of Asghara valley, Sinjavi, District Ziarat. In this study data from 3524 sheep regarding their wool production was collected and analyzed. The animals included in this study were kept by 26 different sheep farmers of Asghara, Marati, Arbosi and Kharawa areas of District Ziarat.. The wool samples were collected from 165 (4.682\%) male, 1438 (40.806\%) female, 771 (21.879\%) male young stock and 1150 (32.633\%) female young stock. The average wool sheared from adult male was highest $(1.90 \mathrm{~kg})$, followed by adult female $(1.80 \mathrm{~kg})$ and male young stock $(1.60 \mathrm{~kg})$; while the lowest $(1.55 \mathrm{~kg})$ was sheared from female young stock. The overall mean yield of white and mixed wool from an adult sheep was 1.75 and $0.10 \mathrm{~kg}$ from young sheep was 1.58 and $0.10 \mathrm{~kg}$ respectively. Most of the sheared wool from sheep (70\%) was marketed; while $30 \%$ was reported to be consumed locally for multiple purposes. At farmers' level, the price of one $\mathrm{kg}$ wool was Rs. 24/-, while the price of white and mix wool was Rs. 28.50 and 19.75 at retail level and Rs. 31.25 and $23.75 / \mathrm{kg}$ at wholesale level. This study concludes that wool quality and quantity may be maximized by adopting modern scientific technologies

Keywords: Fleece production; Shearing techniques; Harnai sheep; Marketing; Season of shearing

\section{Introduction}

The livestock in Pakistan possesses a distinctive position in the national agenda of economic development of the country; providing net source of foreign earnings. This sector is central to the livelihood of the rural poor in the country and can play a key role in poverty alleviation. The socioeconomic condition of Pakistan's rural masses can be improved by providing proper training and implementation of recent advances in said field. During 2014-15, the 
$4.1 \%$ growth has been reported in livestock sector and it has contributed approximately $56.3 \%$ to the agricultural value added and $11.8 \%$ to national GDP [1]. According to the Government of Pakistan Census during, 2012-13, 2013-14 and 2014-15, the livestock population remained, the cattle production $38.3,39.7$ and 41.2 million heads; buffalo 33.7, 34.6 and 35.6 million heads; sheep 28.8, 29.1 and 29.4 million heads; goat 64.9, 66.6 and 68.4 million heads, respectively. This indicates an increasing trend in population of above mentioned animal species during last three years. However, the population of camel is static around one million heads [1].

Among small ruminants, the sheep population is 28.8 million which makes it $18 \%$ of total ruminants [1]. In Pakistan 31 different sheep breeds are documented. In this regard, the peculiarity of Balochistan is that it hosts the four distinct breeds which include Balochi, Beverigh, Harnai and Rakhshani breeds [2] while the Kacchi breed is thin tailed mostly present in southern Punjab [3] About 48\% of sheep population is found in Balochistan. Balochistan is largest province of the country having a land mass of 34.7 million hectares, out of which 93\% land mass comprises of rangelands.

Range based livestock production system is one of the major sources of livelihood for people living in rural areas. The actual carrying capacity of rangelands is limited as compared with the number of small ruminants. This leads to nutritional deficiency for livestock production particularly for sheep and goats in Balochistan [4]. Another study showed that the Chiloé archipelago and Chilota sheep breed showed greater adaptation since under rangeland management and proved more productive and resistant than the Romney Marsh and Suffolk breeds for meat and wool production [5]. However, another study reported no differences between breeds concerning respiratory diseases, mortality or longevity of the ewe due to environmental effect and feeding management [6].

Wool enjoys an important place in Pakistan's economy as it is the basic component of warm cloth and carpet industry. Generally, there are four types of wool which are named as, fine, medium, long and coarse wool. Pakistan is producing coarse wool, which is best one in the world used in the carpet manufacturing and floor covering. Although the quality of wool produced in Pakistan is not suitable for making fine quality thread required in garments industry, however, it is an important input for making thread used in carpet manufacturing [4]. A number of other household products are also indigenously manufactured from using sheep wool thread and hair. The white colored, clean wool fetches relatively higher price as compared to dirty and pale colored one. Similarly the mixed wool is also receiving low price. However, the reflection of incentive for quality wool production in wool price is very little compared to the amount of efforts needed to produce good quality wool [7]. In future, the demand for livestock products is expected to increase at quite higher rates induced by growth in population.

The gain or profit of farmer is dependent on reproductive and production capabilities of the sheep breeds raised [8-10]. Furthermore, differences in productive and reproductive efficiency of sheep breeds also depend on the localities and the management systems employed. When changing from one breed to another or one commodity to another, the reproductive rate, mature body weight and fiber production of the breeds under the farming conditions in question should be considered, as these are the primary factors determining profitability of a specific enterprise [11]. The Kacchi breed compared to other breeds in Balochistan has better reproductive performance, birth weight and 
growth potentials with low lamb mortality rate. Moreover the flocks of kachi breed have a good breeding potential and are welladapted to survive under arid and semi-arid conditions of the region [12]. The Harnai sheep is a fat tail, mutton/wool type breed. They are mostly raised in parts of Loralai, Quetta, Sibi and Zhob districts of Baluchistan province. They are medium size with a white body coat and black or tan spotted head and ears. The wool yield is 2.6 $\mathrm{kg}$ (medium; fiber diameter $33.4 \mu \mathrm{m}$ ). They have a compact body with a small fat tail, high fiber density. Spanish sheep breeds Churra and Castellana [13, 14] are well adapted to local environmental conditions and these breeds produced higher wool production per shearing as compared to Romney Marsh breed. Vazquez and his team reported that Romney Marsh breed showed higher performance in fleece production than the Criollo genetic group $(+1.335$ $\mathrm{kg} / \mathrm{ewe} / \mathrm{shearing}$ ) [15]. Malik and Singh [16] found small and insignificant in Nali ewes and Russian Merino and Corriedale for wool production and F1 was unable to exceed the average production of their parents. Legendre orthogonal polynomials enable model fleece production at any time of the productive life of the individual, as well as to estimate the interaction between heterosis breeding and environment [17]. The environmental effects of year, age, gender and shearing number in the animal are source of important variation on production traits [18].
The current study was primarily aimed at appraising the wool production of Harnai sheep in Asghara valley, Sinjavi, District Ziarat (Balochistan).

\section{Materials and methods}

The Asghara valley (Ziarat district) of Balochistan was selected for the present research. The rangeland and vegetation of this area makes it an ideal valley for the rearing/production of small ruminants. It has potentially more seasonal grasses, shrubs, bushes and ground vegetation. All the data was collected from the farmers of the valley during the activity of wool shearing. The wool production (Shearing) study was conducted during the month of April, 2010. For the study four villages named as Asghara, Marati, Arbosi and Kharawa of Sinjavi were selected. Twenty six (26) farmers were involved for the shearing/collection of wool production data. For this purpose a well-defined Performa was developed to lodge the basic information. The total numbers of sheep in all four groups were three thousand five hundred twenty four (3524) as shown in Table 1. The main objective of this study was to record the wool production farmers practices for wool collection, its marketing system and to identify the difficulties confronted to the farmers for production and marketing. The SPSS/PC computer software was used for simple cross tabulation data analysis.

Table 1. Wool sheering sample collection from Harnai Sheep farmers of Sinjavi valley

\begin{tabular}{|l|c|c|}
\hline Valley & Numbers of Sheep farmers & Total Number of Sheep \\
\hline Asghara & 7 & 767 \\
\hline Marati & 7 & 896 \\
\hline Arbosi & 6 & 869 \\
\hline Kharawa & 6 & 992 \\
\hline Total & 26 & 3524 \\
\hline
\end{tabular}




\section{Results and discussion}

Most of the people of Balochistan province live in rural areas and mainly rely on small ruminants for their livelihood as it serves as a major source of income.. Animal rearing is a high risk commodity than the crop production. In worst case, the crop farmer only loses the seed and other investment, but still has the land. In contrast, the livestock farmers suffer with the loss of parent stock as well as the expected stock [19]. The loss may come due to drought, snow, hailstorms, epidemic and higher incidence of out breaks of certain lethal diseases. Agriculture farmers are able to accumulate and store surpluses whereas; the animal farmers do not have this advantage. The livestock rearing communities of Pakistan in general and Balochistan in particular as status co and social obligation increase progressively with an increase in flock size, which may lead to certain disadvantages of keeping the larger flocks. Overall mean flock size was found 125.86 animals in all four villages and the range was 50 to 350 animals per flock in the research area.

\section{Flock size of the selected farmers}

Overall mean adult and young sheep flock were 801.5 and 960 respectively as shown in Table 2. The percentage of adult male and female sheep ranged from 4.682 to 40.806 whereas, young male and female percentage ranged from 21.879 to 32.633 , respectively (Table 3). It was observed that the number of male is less than the female sheep as female are required for breeding purpose while male are commonly preferred for slaughtering due to the tenderness of their meat (Table 3).

Table 2. Table showing distribution of Classes of Hernia sheep of Asghara valley

\begin{tabular}{|l|c|c|c|c|c|}
\hline Location & Male & Female & $\begin{array}{c}\text { Male Young } \\
\text { Stock }\end{array}$ & $\begin{array}{c}\text { Female } \\
\text { Young Stock }\end{array}$ & Total \\
\hline Asghara & 44 & 322 & 190 & 211 & 767 \\
\hline Marati & 55 & 405 & 150 & 286 & 896 \\
\hline Arbosi & 38 & 356 & 167 & 308 & 869 \\
\hline Kharaw & 28 & 355 & 264 & 345 & 992 \\
\hline Total & 165 & 1438 & 771 & 1150 & 3524 \\
\hline
\end{tabular}

Table 3. Flock composition of small ruminant samples of herders

\begin{tabular}{|l|c|}
\hline Classes & Asghara valley \% \\
\hline Adult Male & 4.68 \\
\hline Adult Female & 40.81 \\
\hline Male Young Stock & 21.88 \\
\hline Female Young Stock & 32.63 \\
\hline Total & 100 \\
\hline
\end{tabular}

\section{Wool shearing practices}

The farmers were not aware of specific protocols and preparations regarding the wool shearing. In general before shearing the sheep must be dipped in anti-parasites solutions and washed for removal of dung, dust and other foreign material attached to wool. Shearing was mostly done by the flock owners by themselves but some of the larger flock's owners hired the professional shearers. . Instead of latest shearing machines, the local shearing scissors (Kharkhol) are not anymore used. The local Kharkhol is of very old fashioned scissors, which has many disadvantages, like it does not shear the wool evenly and prone to make 
cuts on animal body during shearing which leads to wounds and infection. Shearing process lasts for almost for three weeks. During shearing exercise it was revealed that the farmers shear their sheep once a year in spring season and for goats they do shear twice a year in spring and autumn seasons.

\section{Wool production}

The wool production is considered as byproduct and an earning source for the sheep raisers. There are four different breeds of sheep in Balochistan province, Balochi, Harnai, Rakhshani and Bibrik. Balochi sheep breed is raised for production of mutton and wool. Accept Harnai other three sheep breed have course brand wool which is normally used for the rugs, carpets, tents, all types of containers for grain storage and other home-made items etc. Whereas, Harnai sheep wool is considered as somehow near to medium fine type, which is usually used for blankets, suiting, scarf, gloves, and other handicraft items etc. There was a woolen mill at Harnai, famous for blankets and winter suiting, which is now closed since last decade. The average wool production for an adult male, adult female, male young stock and female young stock was $1.90,1.80,1.60$ and $1.55 \mathrm{~kg} / \mathrm{per}$ animal respectively. The overall production of wool from all four locations was $5918.00 \mathrm{~kg}$. Adult male contributed 313.50, adult female 2588.40, young male 1233.60 and young female $1782.50 \mathrm{~kg}$ (Table 4). Martínez and coworker showed that under the agro- ecological conditions had significant effect on wool production of Chilota sheep breed that evidenced a greater adaptation since, in the absence of management practices, it proved more productive and resistant than the Romney Marsh and Suffolk breeds [5]. Kremer and coworkers in Uruguay have reported no differences between breeds concerning respiratory diseases, mortality or longevity of the ewe, maybe because the environmental effect is not as severe [6].

The overall mean yield of white and mixed wool from adult sheep was 1.75 and $0.10 \mathrm{~kg}$ respectively (Table 5). The average yield of white and mixed wool from young sheep was 1.58 and $0.10 \mathrm{~kg}$ respectively. Another study reported significant wool production variability $(\mathrm{P}<0.0001)$ among different sheep breeds. Romney Marsh sheep with the best performance $(2.21 \pm 0.94 \mathrm{~kg}$ of fleece/shearing) than the F1 animals $(1.397 \pm 0.07)$ and the Criollo sheep showed the poorest performance $(0.881 \pm 0.07)$ [15]. Wool production for the first four years of age was similar, and it decreased from the fifth year on; males were $6.9 \%$ superior to females; the first three shearing were similar between them $(\mathrm{P}>0.06)$, but lesser than the last ones $(\mathrm{P}<0.05)$. It has been reported that males produced $6.9 \%$ higher wool production than females; the first three shearing were similar between them $(\mathrm{P}>0.06)$, but lesser than the last ones $(\mathrm{P}<0.05)[15]$.

Table 4. Average wool production from sample of Harnai sheep by farmers (kg per animal)

\begin{tabular}{|l|l|l|}
\hline Classes & Wool production & Total production \\
\hline Adult male & 1.90 & 313.50 \\
\hline Adult female & 1.80 & 2588.40 \\
\hline Young stock male & 1.60 & 1233.60 \\
\hline Young stock female & 1.55 & 1782.50 \\
\hline Total & & 5918.00 \\
\hline
\end{tabular}


Table 5. White and mixed wool production per Harnai sheep

\begin{tabular}{|l|c|}
\hline Type & Adult \\
\hline White & 1.75 \\
\hline Mixed & 0.10 \\
\hline & Young \\
\hline White & 1.58 \\
\hline Mixed & 0.10 \\
\hline
\end{tabular}

Wool consumption and marketing

The marketing of wool as a by-product is always considered an economic activity for the livelihood of the farmers. The data on home consumption and surplus for marketing is presented in Table 6. The results indicated that overall $30 \%$ of total wool produced was used for home consumption by the farmers. The home consumption wool is usually converted into different items by the women. The major bulk of wool production $70 \%$ was sold in the market either in the village, middle man or directly sold in the near town wholesaler. The farmers are not aware of grading and sorting of wool according to its quality which fetch the less price of their commodity. Local traders who are generally big flock owners purchased the wool. Taylor et al. also reported that that the use of technology to develop forward contract selling may have an advantage to the local farmers of the area [19].

Table 6. Wool consumption and marketing in Asghara valley

\begin{tabular}{|l|c|}
\hline Type & Wool percentage of total production \\
\hline Household consumption & 30 \\
\hline Marketing & 70 \\
\hline Total & 100 \\
\hline
\end{tabular}

The data collected regarding sale prices is given in Table 7. Barajas and EstebanMonoz have reported in their research that the main constraints of the wool industry are the lack of quality control, strong competition from traditional wool producing countries and the low status of wool production. Ashton (1998) reported in his study that the low wool prices relative to the prices for other commodities have ultimate result in nominal activity from wool production [20]. The retail price of one $\mathrm{Kg}$ of white and mix wool were Rs.28.50 and 19.50 respectively in local markets. However, the farmers only received Rs. $24 / \mathrm{Kg}$ of wool. Overall mean wholesale price of $1 \mathrm{~kg}$ white and mix wool were Rs. 28.50 and 19.75 respectively. The difference between farmer, retailer and wholesaler price was the marketing margin profited by the intermediaries.

Table 7. Sale price of wool (Rs./kg) received by the sheep farmers

\begin{tabular}{|l|c|}
\hline Type & Sale price \\
\hline Farmer's level & 24 \\
\hline Retail Price & \\
\hline White & 28.50 \\
\hline Mix & 19.75 \\
\hline Wholesale Price & \\
\hline White & 31.25 \\
\hline Mix & 23.75 \\
\hline
\end{tabular}


Secondary, because of low marketable surplus the farmers of the area normally sell their wool at a very nominal/low price. The reason for that the market transportation charges are higher and the poor farmer cannot bear the charges. There no mechanism exists for the grading, sorting practices. Mixing of wool with the dirt and no cleaning also make the consignment less valuable. To strengthen the wool industry in the Balochistan province main step is to channelize the wool collection system. Sorting of wool at the occasion of wool shearing must be practiced. There is essential and basic need to sort out body wool with skirting and colored or mixed wool first hand at producer/farmer level. There is vast potential in improving shearing techniques/machines which are low price and cost effective than the existing situations not only in the study area but also in general in the province. In this regard the training of the farmers at their door step especially at the time of shearing with modern shearing techniques would be an effective tool for the betterment of the wool farmers in particular and wool industry in general. The Government of Balochistan also needs to take initiatives to provide maximum facilitation to the investors to establish wool industry as an enterprise in the province instead of sending all collected wool to the other provinces as raw. There was significant $(\mathrm{P}<0.05)$ variation in wool production between years of study and this variation in Harnai sheep was mainly associated with the animal age. Neupane et al. showed significant variation in yearly wool production of different breeds and additional improvement in wool production was reported on proper management for existing breeds [21]. Mason examined greasy fleece weight, clean fleece weight, mean fiber diameter and eight wool plan selection indices in sheep [22]. The quality of performance records for within-flock selection remained unaffected by nongenetic between-year variation imposed evenly across the entire flock. Between-year variation was induced by animal age and environmental factors such as season and nutritional status. Munir and co-workers [4] reported that the shearing process lasts for nearly two weeks. The production of wool/hair in the autumn season is more than the spring season. Ping and Wang reported that average growth and production rate of wool/hair were faster during the warm season and slowed during the cold season [23]. The shearing of sheep was done twice a year where the hairs of goat were cut once a year. Similar practices of shearing were observed in both, Kovak and Asghara valleys. Shearing of sheep and goats were done with the help of locally made scissors, which are not very effective. Farmers reported that $10-20 \%$ wool/hair is left on the body of small ruminants. The shearing is not uniform in the study area.

\section{Conclusion}

Above all the Livestock and Dairy Development Department, Balochistan is to conserve Harnai sheep breed, which is going to be extinct in the near future in the home tract of Harnai sheep breed. Farmers are crossing female with the Shinwari breed male of Afghanistan, which is black with white patches and has rough wool. As a result the Harnai Woolen Mill had been closed since last decade. Government of Balochistan need to start a subsidiary program for Harnai sheep farmers like it has for Bhagnari cattle subsidiary program by giving incentive to the farmers to keep Harnai breed intact in pure form.

\section{Authors' contributions}

Conceived and designed the experiments: FA Bukhari, S Ahmad \& $M$ Islam, Performed the experiments: FA Bukhari \& T Hameed, Analyzed the data: M Rafique, MZ Mustafa \& BH Abbasi, Contributed reagents/ materials/ analysis tools-: I Ali, 
Wrote the paper FA Bukhari, S Ahmad, TM Asmat \& T Hameed.

\section{References}

1.GOP (2015). Economic Survey of Pakistan, 2014-2015. Ministry of Food, Agriculture and Livestock, Government of Pakistan, Finance Division (Livestock Wing), Islamabad

2.Isani GB \& Baloch MN (1996). Sheep and goat breed in Pakistan. Press Corporation, Karachi, Pakistan. pp: 2329.

3.Jassar M.A (2015). Pakistan Dairy Information. http://www.pakdairyinfo.com

4.Munir M, Shah NA \& Aujla KM (2010). Production of wool and hair in highland Balochistan, Pakistan. Pak. J. Agri., Agril. Engg., Vet. Sci 2010, 26(1): 7587.

5.Martínez ME, Calderon C, Uribe H \& De la Barra RA (2012). Effect of management practices in the productive performance of three sheep breeds in the Chiloé Archipielago Chile. J. Livestock Sci 3: 57-66.

6.Kremer R, Barbato G, Rista L, Roses L \& Perdigon F (2010). Reproduction rate, Milk and wool production of corridale and East Friesian x Corridale F1 ewes grazing on natural pastures. Small Rumin. Res 90: 27-33.

7.FAO (1987). Production Yearbook. Food and Agriculture Organization. Rome, Italy.

8. Hanford KJ, Vleck VLD \& Snowder GD (2002). Estimates of genetic parameters and genetic change for reproduction, weight, and wool characteristics of Columbia sheep. Journal of animal science 80(12): 3086-3098.

9.Leymaster K (2001). Evaluation of Wool and Hair Breeds under Intensive and Extensive Production Systems. PhD, USDA-ARS, U.S. Meat Animal
Research Center, Clay Center, Nebraska.

10. Zubair M, Habib G \& Ahmad N (2006). Comparative Study on Wool Yield and Wool Quality in Sheep Reared at Livestock Reach Station Jaba and Lalazar Alpine Pasture. Journal of Animal and Veterinary Advances 5(8): 641-646, 2006.

11. Komprej A, Gorjanc G, Kompan D \& Kovac M (2012). Lactation curves for milk yield, fat, and protein content in Slovenian dairy sheep. Czech J. Anim. Sci 57(5): 231-239.

12. Lashari MH \& Tasawar Z (2010). Genetic Potentials of local breed of sheep habitating around Dera Ghazi Khan, Pakistan. Sarhad J. Agric 26(2): 251-258.

13. De la Barra RA, Carvajal A, Uribe H, Martínez MM, Gonzalo C, Arraz J \& Primitivo SF (2011). El ovino criollo y su potencial productivo, Animal Genetic Resourses FAO. 48: 93-99.

14. De la Barra R, Martínez ME \& Calderón C (2014). Phenotypic featrures and fleece quantitative traits in Chilota sheep breed. Livestock Sci 5: 28-34.

15. Vazquez CG, Muniz JGG, Villalobos NL, Villalobos JMB, Villagomez PP \& Aguirre EF (2015). Wool production of Romney Marsh Criollo Chiapas sheep breed and their crosses analyzed by random regression. Int. J. of Livestock Prod 6 (9) : 99-108

16. Malik BS \& Singh RP (2006). Evaluation of crossbreeding effects for wool traits in sheep. Asian-Aust. J. Anim. Sci 19(11): 1536-1540.

17. Su G, Madsen P \& Lund MS (2009). Reaction norm model with unknown environmental covariate to analyze heterosis by environment interaction. J. Dairy Sci 92: 2204-2213.

18. Hassen Y, Sölkner J \& Waltl BF (2004). Body weight of Awassi and indigenous 
Ethiopian sheep and their crosses. Small Rum. Res 55: 51-56.

19. Buzdar N, Nagy JG, Farid Sabir G \& Keatinge JDH (1989). Animal Raising in Highland Balochistan: A Socioeconomic perspective. MART/AZR Research Report No. 50. Quetta: AZRI.

20. Taylor N, Hatfield PG, Sowell BF \& Lewis GS (2002). Research Note Influence of supplement form on ewe performance and reproduction. Sheep and Goat Res. J 17(2): 52-54.

21. Ashton D (1998). Australian wool production: it's changing structure in the 1990s. Australian-Commodities 5(3): 366-373.

22. Neupane D, Dhaubhadel T \& Neopane SRP (2010). Evaluation of Wool Production Performance on Different
Lines and Strains of Angora Rabbit at Khumaltar, Lalitpur. Nepal Journal of Science and Technology 11: 83-86.

23. Mason DA (1998). Repeatability of performance rankings and wool production characteristics of merino ewes in a semi-arid farming environment. M.Sc. Thesis submitted to University of Adelaide, Dept. of Animal Science, Australia.

24. Ping WS \& Wang SP (1999). The influence of different grazing systems on wool production and qualities of Chinese merino fine sheep in Inner Mongolian steppe. Inner Mongolia Grassland Ecosystem Research Station, Institute of Botany, CAS, Beijing 100093, China. Acta Prataculturae-Sinica 8(3): 22-30. 